\title{
A Case of Adrenoleukodystrophy
}

\author{
Young Hwue Kim, Soon Ki Kim, Sei Won Yang, Hyung Ro Moon and Je G. Chi \\ Department of Pediatrics and Pathology*. College of Medicine, Seoul National Unizersity Children's Hospital \\ Seoul Vational Unirersity, Seoul 110-7tt, Koreda
}

\begin{abstract}
$=$ Abstract $=$ Adrenoleukodystrophy is a rare genetically determined disorder associated with progressive white matter degeneration of central nervous system.

Although it is known to occur in most parts of the world it is seldom reported in Korea. We report a case of adrenoleukodystrophy in a 6 year old boy that was diagnosed by adrenal biopsy and demonstration of characteristic cryptalloid inclusions seen in adrenal cortical cells. This patient also had a widespread white matter lesion and brain atrophy that could clearly be demonstrated with Magnetic Resonance Image.
\end{abstract}

Key words: Adrenoleukodystrophy, Adrenal cortex, Leukodystrophy

\section{INTRODUCTION}

Adrenoleukodystrophy (ALD) is genetically determined disorder associated with progressive central demyelination and adrenocortical insufficiency. All affected persons show increased levels of saturated unbranched very long chain fatty acids (ULCFA), particularly hexacosanoate(C 26:0). Clinically varying degrees of adrenal insufficiency are associated with a rapid progressive neurologic disorder of the white matter, resulting in blindness, quadriparesis, dementia and death.

We experienced a 6-year old boy with adrenoleukodystrophy, and so report him with review of literatures.

\section{CASE REPORT}

This 6 year old boy was amditted to the pediatric ward with the chief complaints of motor deficit and seizure. In October 1986, his mood seemed depressed and somewhat drowsy. But his parents neglected it. One month later, fever, headache and vomiting developed and was followed by seizure of generalized tonic-clonic type. So he had some medication for seizure. In January 1987, abnormal gait and dysarthria developed, which was progres-

Received 22/4/88;revised 18/5/88;accepted 20/5/88 sive inspite of medication.

On admission, he seemed dull and depressed, but orientation was intact. His motor response to verbal order was inappropriate. Optic discs were atrophied bilaterally. Skin pigmentation was observed, especially on axilla, umbilicus, both nipple areas and groin. Deep tendon reflex was enhanced moderately and cerebellar function was distorted.

24 hour urine concentration of 17-KS and $17-\mathrm{OHCS}$ were $4.2 \mathrm{mg} / \mathrm{d}$ and $2.2 \mathrm{mg} / \mathrm{d}$, respectively. The diurnal rhythm of cortisol secretion was absent (plasma level of cortisol; $9.8 \mathrm{ug} / \mathrm{dl}$ at 8:00 AM and $5.0 \mathrm{ug} / \mathrm{dl}$ at 8:00 PM). The response of cortisol secretion to ACTH stimulation was not elicited. The findings of MRI scan consisted of a mild degree of diffuse ventricular dilatation, prominence of cisternal space suggesting mild brain atrophy on T1-weighted image and symmetric high singal intensity were noted in both periventricular region of occipital horn of lateral ventricle and the peripheral margin of the high signal intensity was speculated and extending into the cortical gray matter.

\section{PATHOLOGIC EXAMINATION}

A $2 \times 1 \times 0.7 \mathrm{~cm}$ sized adrenal tissue was submitted, surrounded by periadrenal fat. Cut sections showed a thin but bright yellow cortex measuring less than $1 \mathrm{~mm}$ in thickness. The medulla was gray 


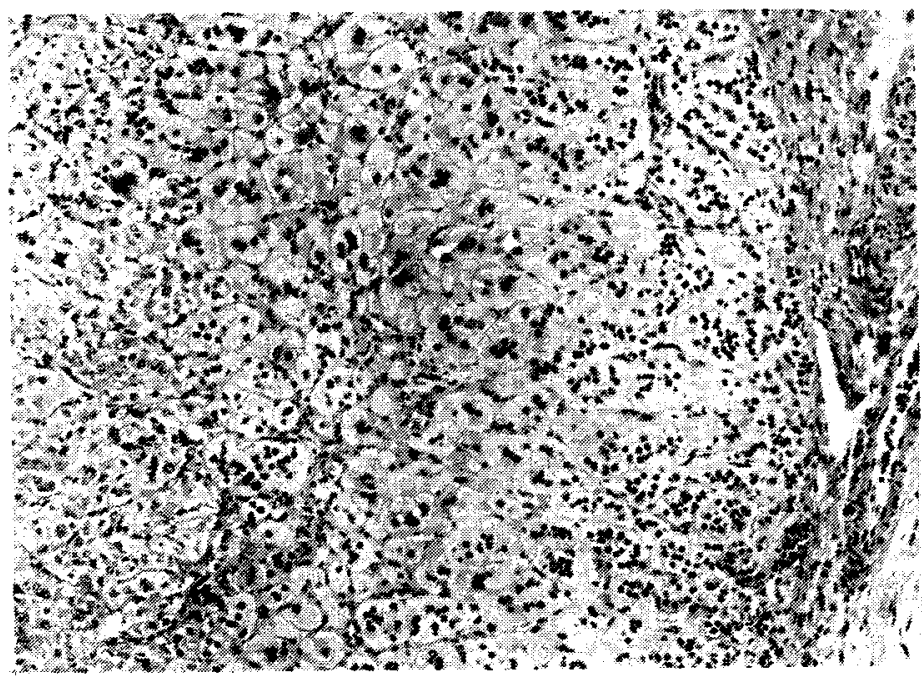

Fig. 1. Photomicrograph of adrenal biopsy specimen, showing cortical atrophy and distortion of zona fasciculata and zone reticularia. (H\&E X100)

white and prominent.

Microscopically the cortex was characterized by a diffuse atrophy and thinning, with distortion of zona fasciculata and reticularis (Fig. 1). There were scattered collections of ballooned cells and multinucleate giant cells with glassy homogeneous pinkish cytoplasm (Fig. 2). The cortex was fairly well distinguished from underlying medulla which was relatively prominent and showed scattered collections of lymphocytes.

Electron microscopically ballooned cells in the cortex showed numerous cryptalloid clefts (Fig. 3). Multilamellar structures and structures resembling twisted of flowing multilamellar forms were inded (Fig. 4). Lamellae consisted of two parallel $25 \mathrm{~mm}$ thick electorn dense leaflets separated by a variable electron-lucent space. Round bodies with vacuolar inclusions were also noted.

\section{DISCUSSION}

Since initial report of adrenoleukodystrophy by Siemerling and Creutzfelt in 1923, similar isolated cases had been reported subsequently. In general, there are three different trypes of ALD; childhood type, adrenomyeloneuropathy (AMN) and the entirely separated neonatal or connatal form.

The possible contributing factor of adrenal insufficiency is that the abnormal fatty acid composition of the adrenal cholesterol ester may impair availability of the cholesterol for normal steroidogenesis. But the pathogenesis of ALD is not understood yet.

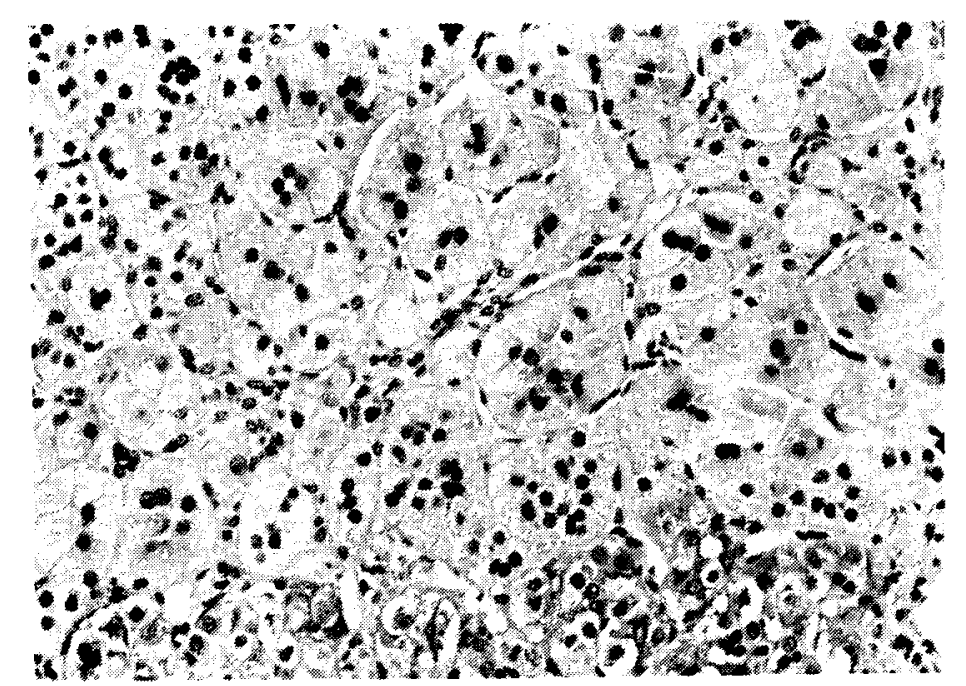

Fig. 2. Higher magnification of adrenal cortical cells, showing ballooning of cytoplasm and giant cell formation. (H\&E X250)

The rapid progression of the disease, the asymmetrical distribution of the lesion, and the striking accumulations of lymphocyte in active brain lesion suggest immunopathogenic mechanism. Childhood $A L D$ is transmitted through sex-linked recessive trait.

The development of abnormal behavior and distrubance of vision or gait in a young boy should suggest a diagnosis of ALD. If there is any demonstrable evidence of diminished adrenocortical function, the diagnosis is invariably certain. The signs of CNS distrubance are consistently more prominent than the signs of adrenal insufficiency. Usually, behavioral change is the initial finding, ranging from withdrawn state to bizarre aggressive outburst. Disturbance of gait is also an early finding. Other findings which are usually observed are dysarthria, dysphagia, hearing loss, visual loss with optic atrophy, seizure, hemiparesis and eventually quadriplegia and death.

Symptoms and signs of adrenal insufficiency are insiduous in onset and they are generalized weakness, intermittent vomiting, cutaneous pigmentation and hypotension. They develop pari passau with the neurologic disorders.

Neonatal or connatal ALD differs strikingly from childhood ALD. Apart from earlier onset and profound disabilities, severe seizure are observed frequently. The liver is usually enlarged with impaired function. Females are as severely involved as males. So the pattern of inheritance appears to be 


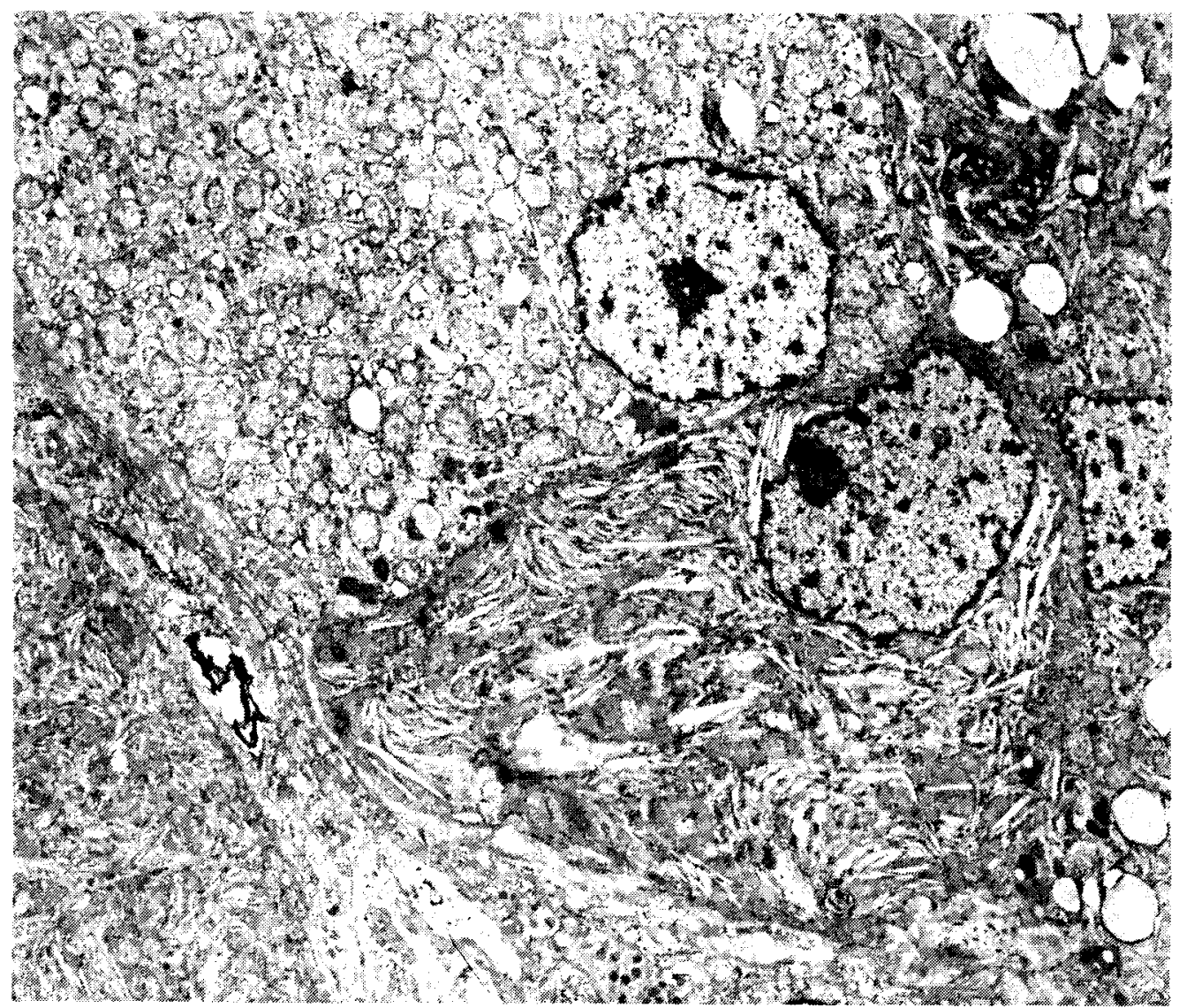

Fig. 3. Electron micrograph of adrenal cortical cells showing numerous intracytoplasmic crystalloid inclusions. (Lead citrate $\mathrm{X7500)}$

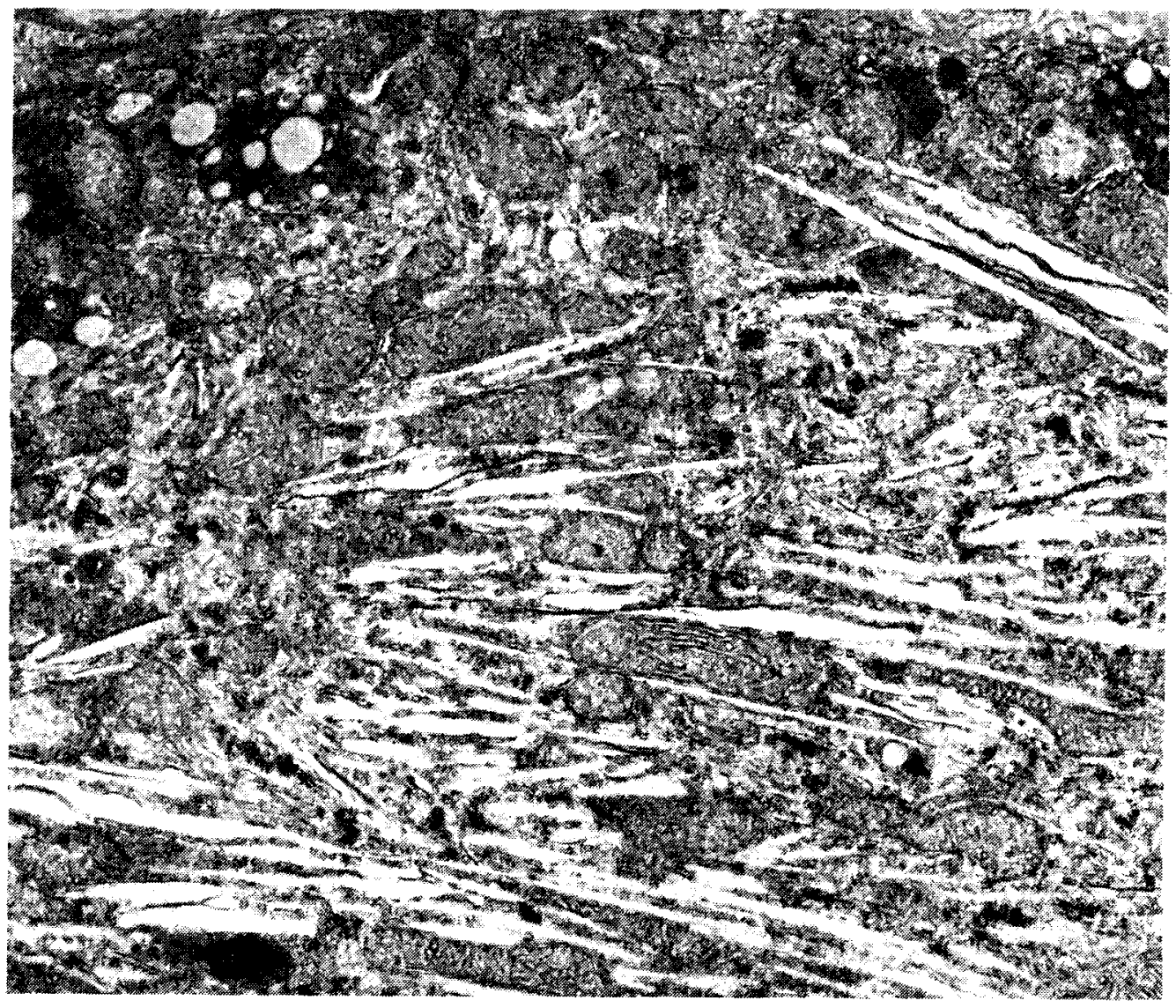

Fig. 4. Electron micrograph of cytoplasmic inclusions, showing paralled structure. (Lead citrate X20000) 


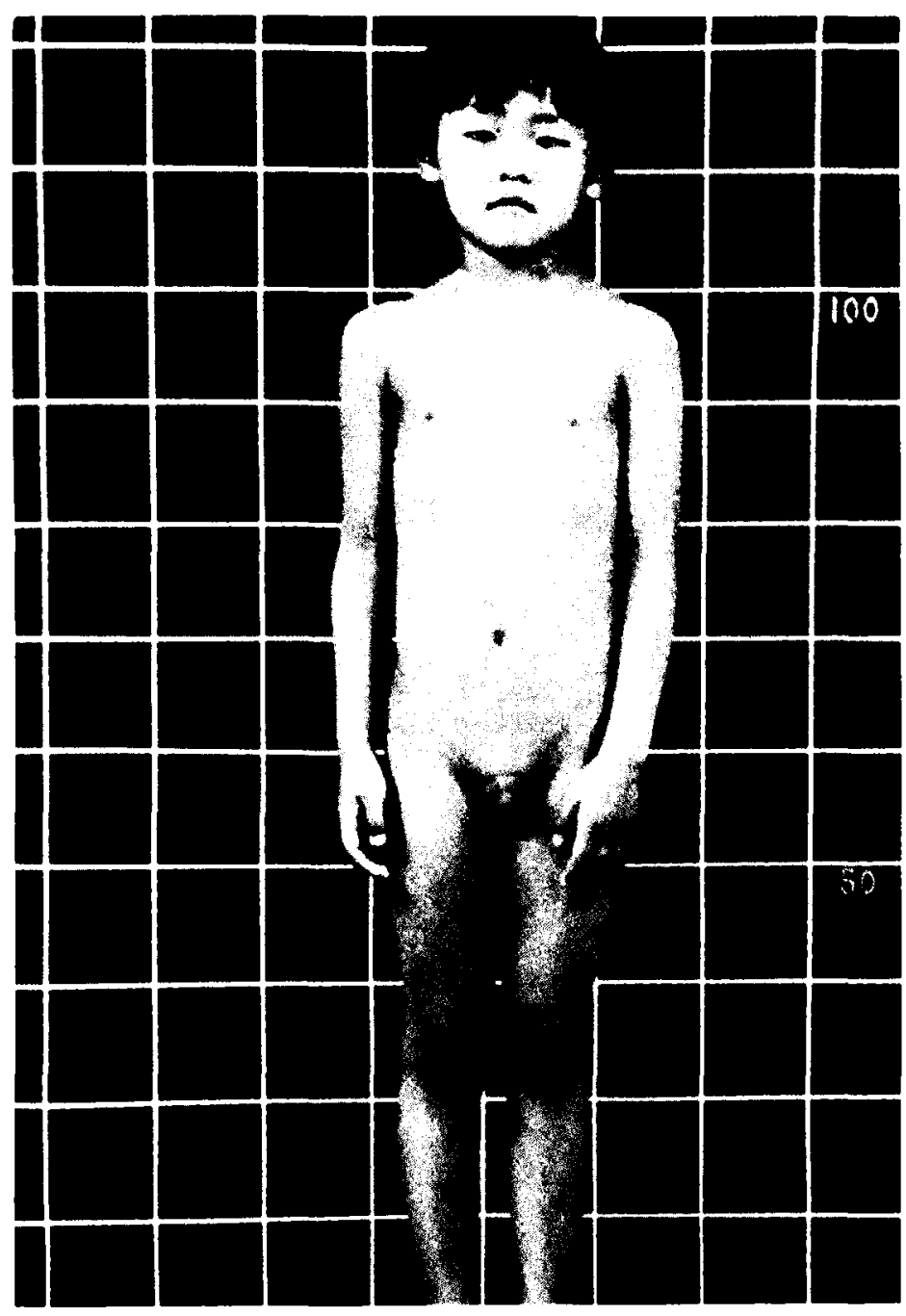

Fig. 5. General body appearance of the patient: He seems dull and increased pigmentation of the skin was noted at both nipple areas, umbilicus axilla, groin.

autosomal recessive.

Diagnosis is suggested by clinical and laboratory findings of primary adrenal failure and by neurological sings referable to the degeneration of the white matter. Confirmative diagnosis can be drawn by adrenal biopsy and biochemical assay for VLCFA. The single most reliable test for disagnosis has been found to be an open adrenal biopsy. Measurement of VLCFA, especially hexacosanoate is the most sensitive test for the diagnosis of ALD.

Most heterozygous women for ALD can be detected by the assay of VLCFA. The fetus with ALD can be detected prenatally by the measurement of VLCFA in amniotic fluid.

There is not any satisfactory treatment for ALD and once the first symptoms referable to the CNS appear, the course is always that of relentlessly
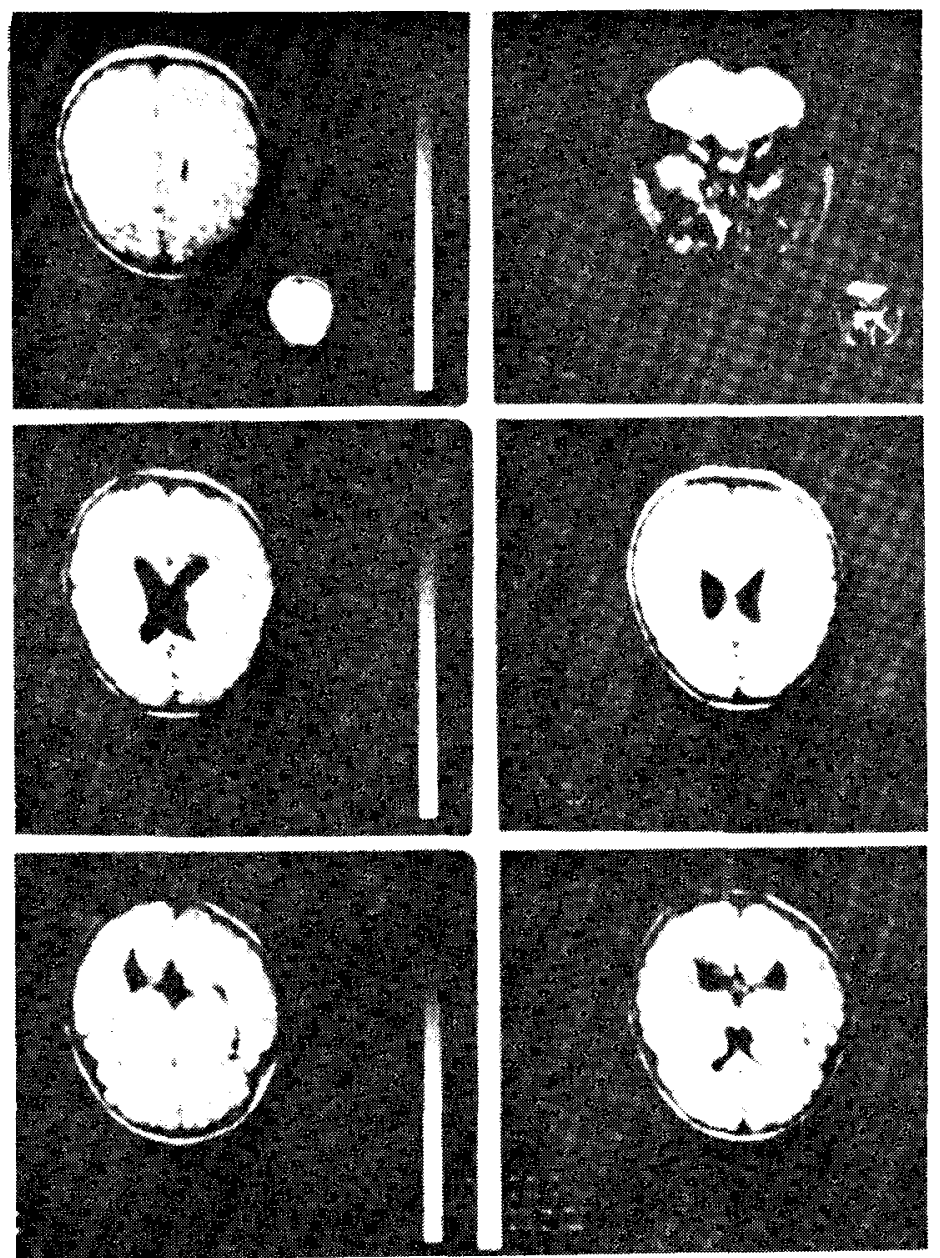

Fig. 6. MRI brain scan; T1-weighted image. Mild degree of diffuse ventricular dilatation and prominancy of cisternal space suggesting mild brain atrophy.

progressive neurologic deterioration. In 1975, Herber reported that the duration of illness was ranging from 9 months to 9 years.

\section{REFERENCES}

Hugo W, Moser MD, Moser AEAB, Singh I, O'Neill BP. Adrenoleukodystrophy; Surevey of 303 cases; Blochemistry, diagnosis and therapy. Ann. Neurol. $1984,16: 628-641$

Herbert H, Scharmburg MD, Powers TM, Raine CS, Suzuki K, Richardson EPJr. Adrenoleukodystrophy, A clinical and pathological study of 17 cases. Arch. Neurol. 1975, 32:577-591

Gary M, Weiss MD, Nelson RL, O'Neill BP, Carney AJ, Edis AJ. Use of adrenal biopsy in diagnosing adrenoleukodystrophy. Arch Neurol. 1983, 30:634-636

Allen JP, Kepic T, Garwacki D, Yunus M. Adrenal defect in adrenomyeloneuropathy. South Med. J. 1982, 75:877-879

Brown FR III, McAdm AJ, Cummins JW. Cerebrohepa- 

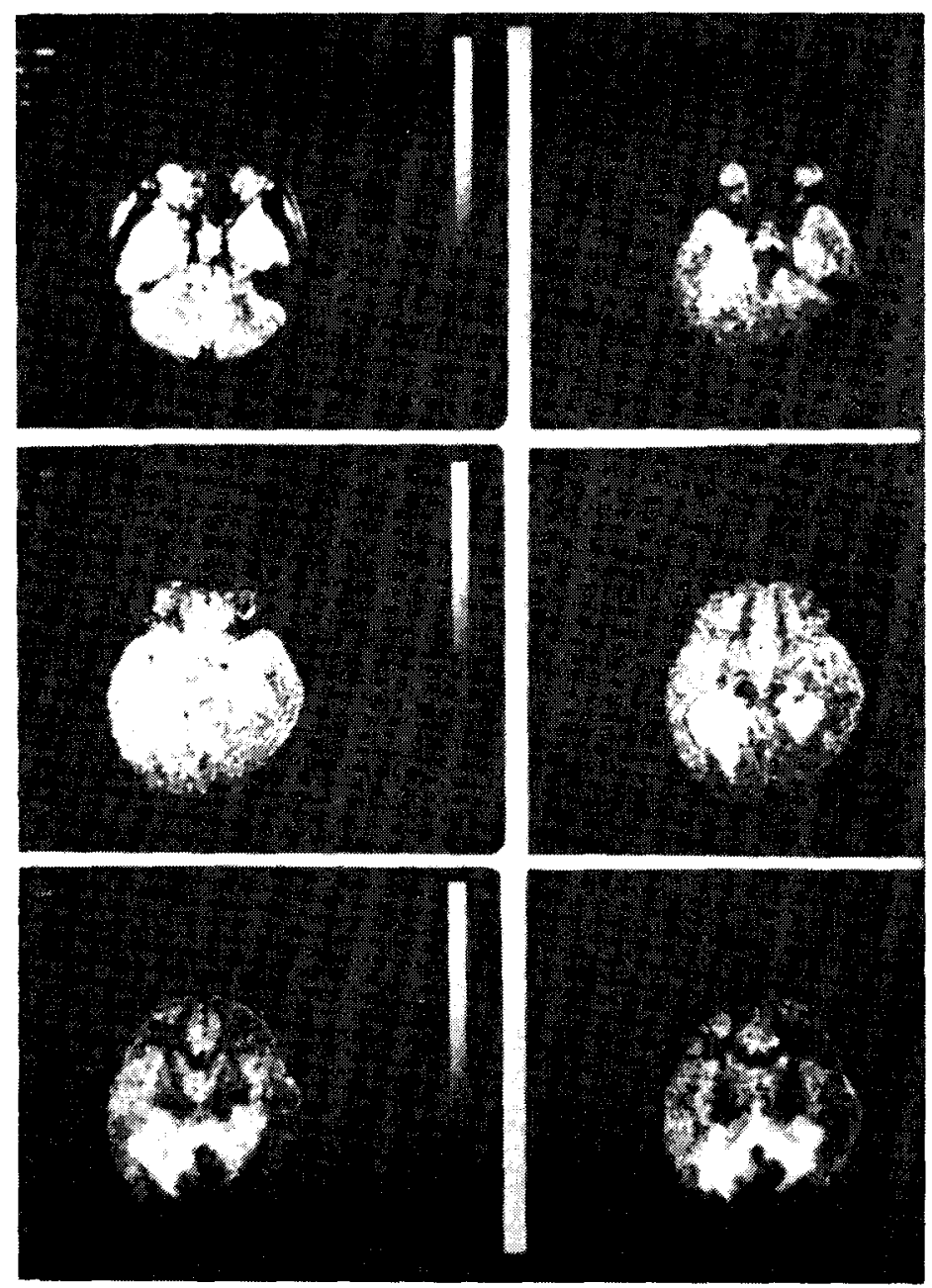

Fig. 7. MRI brain scan; T2-weighted image. Symmetric high signal intensity are noted in both periventricular region of occipital horn of lateral ventricle and the peripheral margin of the high signal intensity are speculated and extending into cortical gray matter. torenal (Zellweger) syndrome and neonatal adrenoleukodystrophy; Similarities in phenotype and accumulation of very long chain fatty acids. Johns hopkins Med. J. 1982, 155:344-351

Jeffe R, Crumrine P, Hashida Y. Moser HW. Neonatal adrenoleukodystrophy; Clinical, pathological and biochemical delineation of a syndrome affecting both males and females. Am. J. Pathol. 1982, 108:100-111

Moser HW, Moser AB, Frayer KK, Chen W, Schulman JP, O'Neill BP, Kishimoto Y. Adrenoleukodystrophy; increased plasma content of saturated very long chain fatty acids. neurology (NY) 1981, 31:1241-1249

Moser HW, Moser AB, Powers JM, Nitowsky HM, Schaumburg $\mathrm{HH}$, Norum RA, Migeon BR. The prenatal diagnosis of adrenoleukodystrophy; Demonstration of increased hexacosanoic acid in cultured amniocytes and fetal adrenal gland. Pediatr. Res. 1982, $16: 172-175$

Moser HW, Moser AB, Trojak JE, Supplee SW. Identification of female carriers for adrenoleukodystrophy. J. Pediatr. 1983, 103:54-59

Noetzel MJ, Clark HB, Moser HW. Neonatal adrenoleukodystrophy with prolonged survival. Ann. Neurol. 1983, 14:380

Siemerling E, Creutzfelt HC. Bronzekrnkheit und skleroriesende encephalomyelitis (diffuse sclerose). Arch. Psychiatr. 1923, 68:217-244

Woods. DNA probes and carriers of $X$-linked disease(letter). Lancet 1982, 2;1219-1220

Powers JM, Schaumburg HH. Adrenoleukodystrophy; Similar ultrastructural changes in adrenal cortical cells and Schwann cells. Arch. Neurol. 1974, 30:406-408

Powell H, Tindall R, Schultz P. Adrenoleukodystrophy; electron microscopic findings. Arch. Neurol. 1975, 32:250-260 
$=$ 국문초록 $=$

\title{
부신 뇌백질 이양증(1증례 보고)
}

\author{
서울대학교 의과대학 소아과학교실 및 병리학교실* \\ 김영휘 · 김순기 · 양세 원 · 문형로 · 지제근*
}

부신 뇌백질이양증은 성염색체 열성으로 유전되며 4 8세에 호발하는 질환으로 신경학적 증상 과 부신기능 저하증상을 나타낸다. 신경학적 증상이 더 잘 나타나 행동변화 및 치매가 최초의 증 상이며 그 이외에 걸음걸이의 장애, 심건반사 항진, 구음 장애, 연하 장애, 시력감퇴, 청각장애, 마비, 경련 등이 나타나며 부신피질기능저하로 표피 색소 침착, 피로감, 간헐적인 구토, 저혈압 증 둥이 나타난다.

이 질환에서는 모든 환아에서 hexacosanoate의 농도가 증가되어 있기때문에 여성 heterozygote감지 및 prenatal 진단에 이용되고 있으며 이 질환의 의심이 있으면 뇌생검보다는 부신생 검 이 더 효과적인 진단 방법으로 이용될 수 있는 것으로 생각된다.

저자들은 표피색소 침착 및 걸음걸이 장애 및 시력감퇴를 나타낸 6세 남아에서 부신생 검을 시 행하여 부신 뇌 백질이양증과 일치하는 소견을 발견하여 문헌고찰과 함께 보고하는 바이다. 